\title{
Bilimsel Tutum Ölçeği Geliştirme: Geçerlik ve Güvenirlik Çalışması
}

\author{
Developing a Scientific Attitude Scale: Validity and Reliability Study*
}

Berna KEÇE ${ }^{1}$, Sibel SARAÇOĞLU ${ }^{2}$, Oktay BEKTAŞ ${ }^{3}$

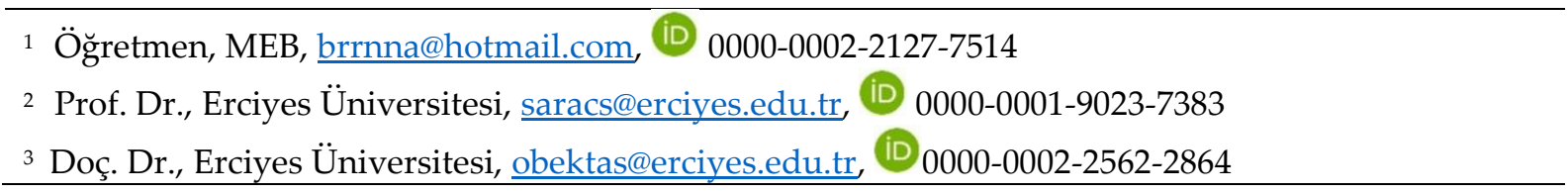

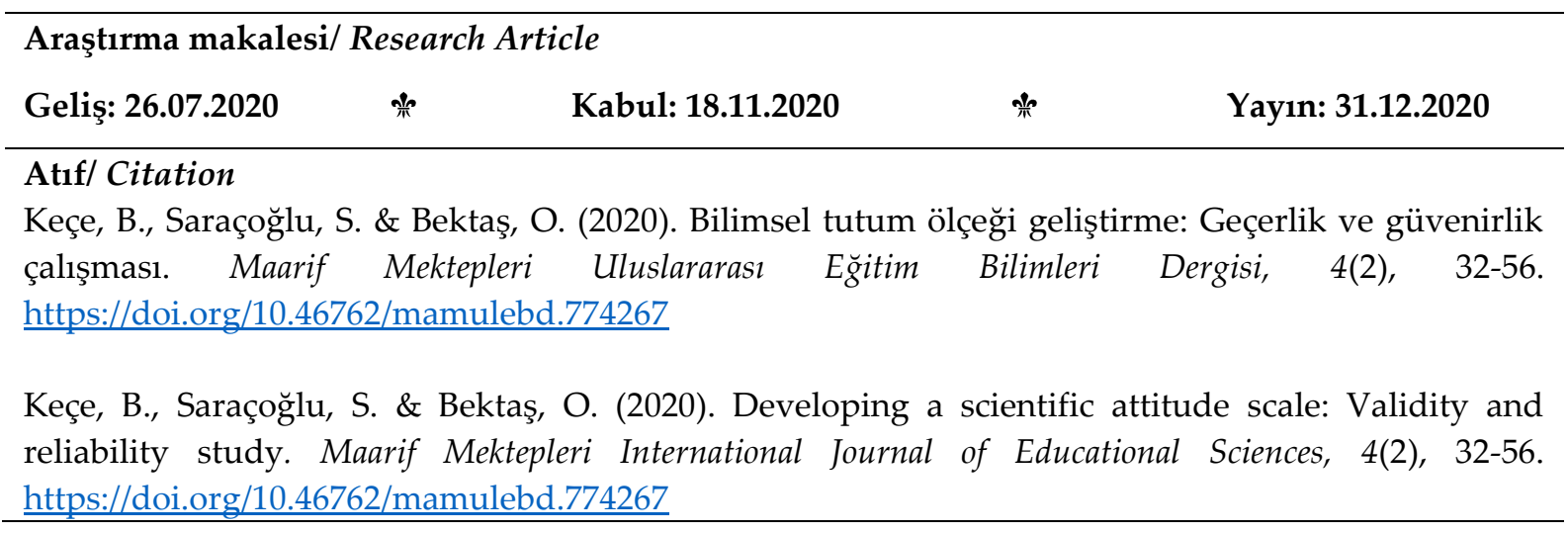

Öz

$\mathrm{Bu}$ çalışmanın amacı, bilimsel düşünebilen bireyler olarak yetişebilmeleri için lise öğrencilerinin bilimsel tutumlarını belirleyen bir ölçek geliştirmektir. Bu çalışmada bir ölçeğin geliştirilebilmesi amacıyla ilgili örneklemin bilimsel tutumlarına ilişkin düzeyleri taranacağından nicel araştırma yönteminin bir deseni olan tarama kullanılmıştır. Ölçek geliştirme sürecinde öncelikle alan yazın taraması yapılarak, benzer ölçeklerin incelenmesiyle 56 maddelik bir madde havuzu oluşturulmuştur. Beşli Likert tipinde oluşturulan ölçeğin, geçerlik ve güvenirlik çalışmaları yapılmıştır. Çalışmanın örneklemini üç farklı lise türünde eğitim gören 602 öğrenci oluşturmaktadır. Ölçeğin kapsam geçerliğini sağlamaya yönelik uzman görüşleri alınmıştır. Ölçeğin ölçüt geçerliğini sağlamak adına Pearson korelasyon katsayısı değeri 0,79 bulunmuştur. Ölçeğin yapı geçerliğini belirlemek üzere; açımlayıcı ve doğrulayıcı faktör analizleri yürütülmüştür. Açımlayıcı ve doğrulayıcı faktör analiziyle "Bilimsel Davranış Sergileme”, "Bilim İnsanlarının Özellikleri”, "Bilim ve Toplum" ve "Bilimsel Bilginin Özellikleri" olmak üzere dört faktörlü ve 27 maddeden oluşan bir yapıya ulaşılmıştır. Doğrulayıcı faktör analizi de açımlayıcı faktör analizi sonuçlarını doğrulamıştır. 
Ölçeğin güvenirliği için, ölçeğin tamamının ve alt faktörlerin iç tutarlık katsayıları kontrol edilmiştir. Elde edilen Cronbach's Alpha iç tutarlık katsayısı ölçeğin tümü için, 0,87, “Bilimsel Davranış Sergileme” faktörü için 0,86, “Bilim İnsanlarının Özellikleri” faktörü için 0,70, "Bilim ve Toplum" faktörü için 0,75 ve "Bilimsel Bilginin Özellikleri" faktörü için 0,78 olarak tespit edilmiştir. Yapılan analizlerle Bilimsel Tutum Ölçeğinin, lise öğrencilerinin bilimsel tutumlarını tespit etmek amacıyla kullanılabilir, geçerli ve güvenilir bir araç olduğu belirlenmiştir.

Anahtar Kelimeler: Bilimsel tutum, ölçek geliştirme, geçerlik, güvenirlik, lise öğrencileri

\section{Abstract}

The aim of this study is to develop a scale that determines the scientific attitudes of high school students so that they can grow up as individuals who can think scientifically. In this study, survey, which is a design of quantitative research method, was used since the scientific attitudes levels of the relevant sample were determined in order to develop a scale. During the scale development process, firstly, literature review was conducted to create a pool of 56 items. The validity and reliability studies were performed. The sample of the study consisted of 602 students studying in three different high school types. Expert opinions were taken to ensure the content validity. The Pearson correlation coefficient value was found to be 79 to provide the criterion validity. To determine the construct validity; exploratory and confirmatory factor analyzes were completed. Then, item discrimination indices were calculated. With the exploratory and confirmatory factor analysis, a structure consisting of four factors and 27 items, namely "Scientific Behavior Display", "Characteristics of Scientists", "Science and Society" and "Characteristics of Scientific Information" was reached. The Cronbach's Alpha internal consistency coefficient obtained was .87 for the entire scale, .856 for the first factor, .70 for second the factor, .75 for the third factor, and .78 for the final factor. It is determined that the Scientific Attitude Scale is valid and reliable that can be used to determine the scientific attitudes of high school students.

Keywords: Scientific attitude, scale development, validity, reliability, high school students

\section{Giriş}

Günümüzde yeni bilgiler üretebilen, yaratıcı ve bilimsel düşünebilen bireyler yetiştirmek gelişmiş toplumların amacıdır. Bu kapsamda ülkelerinin ileriye götürmeyi hedefleyen toplumlar, araştıran, sorgulayan, açık fikirli, ön yargıları olmayan, duygu ve düşüncelerini özgürce ifade edebilen bireylerin yetiştirilmesine önem vermektedirler (Erdem, 2012). Bu doğrultuda ülkeler eğitim programlarının amaçlarını bireylerin bilişsel, duyuşsal ve psikomotor becerilerinin geliştirilmesine yönelik düzenlemektedirler. Yapılan araştırmalarda ise eğitim sürecinde daha çok bilişsel amaçların ön planda olduğu ve duyuşsal hedeflerin ihmal edildiği belirtilmektedir (Bacanlı, 2005; Demirbaş ve Yağbasan 2005). Milli Eğitim Bakanlığı (MEB) ortaöğretim programları incelendiğinde de duyuşsal amaçların geri planda kaldığ1 görülmektedir (MEB, 2018). Oysa duyuşsal kazanımlar diğer öğrenme alanlarının gelişimini de etkilemektedir (Gömleksiz ve Kan, 2012). Nitekim duyuşsal becerilerin, yetişmekte olan bireylerin topluma sağlıklı bir şekilde uyum sağlamalarına katkıda bulunduğu ve istenilen davranışı ortaya çıkarmaya yardımcı olduğu bilinmektedir (Gömleksiz ve Kan, 2012). Duyuşsal alan, bireylerin olumlu veya 
olumsuz duygu ve düşüncelerine yön veren, onları şekillendiren tutum, ilgi, inanç gibi alt boyutları kapsamaktadır. Duyuşsal alanın alt boyutlarından birisi olan tutum, bireyin davranışlarına ve karar verme sürecine yön vermede etkili olduğu düşünülen bir olgudur (McCoach, Gable ve Madura, 2013). Bilimsel tutum, problem çözmeyi, bilgi üretmeyi, araştırmayı ve öğrenmeyi kolaylaştıran düşünce ve davranışlar olarak ifade edilmektedir (Olasehinde ve Olatoye, 2014). Bu nedenle eğitim sisteminin temel amaçlarından birisi de bireylerin bilimsel davranış ve tutumlarının geliştirilmesidir (Büyüköztürk, 1999). Bilimsel tutumların, farklı fikirlere açık olmak, olaylara şüpheyle yaklaşabilmek, başarısız olmaktan korkmamak, sabırlı ve dikkatli olmak, yapılan başka çalışmalardan hareketle araştırmasına yön verebilmek, yaptığı çalışmada hata yapma olasılığının olabileceğini kabul ederek araştırma yapmak gibi birçok özelliği kapsadığ1 görülmektedir (Carin ve Bass, 2001, s. 33). Bu özellikler; objektif karar verebilen, araştırmaya meraklı, yaratıcı düşünebilen, yeni bilgilere açık olan, değişken olan durumlara uyum gösterebilen, yani bilimsel düşünmeyi başarabilen insanı tanımlamaktadır. Dolayısıyla, bilimsel tutumların geliştirildiği toplumlarda; bilimsel düşünebilen ve sağlıklı kararlar verebilen bireyler yetiştirilmesi hedeflenmektedir.

Bireylerde bulunması gereken pek çok beceri, sahip olunan bilimsel tutumdan etkilenmektedir. Örneğin bireylerin sahip olduğu bilimsel tutum, bilimsel düşünme, bilime olan bakış açısı, bilimsel bilginin oluşum sürecini kavrayabilme ve bilim insanlarının özelliklerine karşı bakış açısı gibi birçok olguyu etkilemektedir (Duran, 2008). Dolayısıyla farklı öğrenim seviyesinde büyük hedefleri olan bireylerin, bilimsel düşünebilmeleri, bilimin topluma vereceği katkı hakkında bilgi sahibi olmaları ve günlük hayattaki problemleri bilimsel yöntemleri kullanarak çözebilme gibi davranışları kazanmaları oldukça önemlidir. Alan yazına bakıldı̆̆ında bilimsel tutumun küçük yaşlarda kazanıldığı görülmektedir (Jewett, 1996). Bununla birlikte, bireyin erken yaşlarda edindiği bilimsel tutum zamanla bireyin kazandığı deneyimler doğrultusunda olumlu veya olumsuz yönde değişim gösterebilir (Chan ve Bauer, 2015; Cheung, 2009). Dolayısıyla, bu değişim bireylerin üniversite ve meslek seçimlerini de etkileyebilir (Brown, Sharma, Wakeling, Naiker, Chandra, Gopalan ve Bilimoria, 2014). Öğrenciler lise çağında olumlu bilimsel tutum geliştirdikleri derslerle ilişkili olan bölümleri seçmeye eğilim gösterebilir, olumsuz tutuma sahip oldukları derslerle ilişkili olan bölümleri seçmekten kaçınabilirler. Dolayısıyla, lise çağındaki bireylerin bilimsel tutumlarının belirlenmesi bilimle ilişkili ders seçimlerine, öğrenme durumlarına ve gelecekteki meslek seçimlerine olumlu anlamda katkı sunabilir (Nieswandt, 2007). Bir başka ifadeyle, lise eğitimiyle birlikte tam anlamıyla şekillenen bilimsel tutumlar, bu seviyedeki bireylerin bilimsel tutum ve doğru karar verme süreçlerini geliştirmelerine katkıda bulunmakla birlikte üniversite öğrenimleri süresince, bilimsel olaylara doğru bir bakış açısıyla bakma gibi olguları geliştireceğinden üniversite eğitimini de olumlu etkileyecektir. Dolayısıyla bu çerçevede olumlu bilimsel tutumlara sahip lise çağında olan genç yetişkin bireylerin yetiştirilmesi oldukça önemlidir. Türkiye İstatistik Kurumu (TUIK) "İstatistiklerle Gençlik 2018 Raporu" Türkiye nüfusunun \%15,8'ini 15-24 yaş arasındaki gençlerin 
oluşturduğunu belirtmektedir (TUIK, 2018). Belirtilen aralıkta lise öğrencileri de yer almaktadır ve bu aralıktaki bireyler toplumun en dinamik, aktif ve hareketli kesimidir. Dolayısıyla dinamik ve aktif lise öğrencilerinin bilimsel tutumlarını belirlemek onların gelecekteki bilimsel tutumlarını düşürmelerinin önüne geçebilir çünkü öğrencilerin sınıf düzeyleri ve yaşları büyüdükçe fen bilimine ve fen derslerine yönelik tutum puanlarının düştüğü görülmektedir (Baykul, 1990; Demirbaş ve Yağbasan, 2006; Hadden ve Johnstone, 1983). Bu kapsamda gerek “Uluslararası Yetişkin Becerilerinin Ölçülmesi Programı" (PIAAC) gerekse "Uluslararası Öğrenci Değerlendirme Programı" (PISA) sonuçları, Türkiye'deki lise öğrencilerinin meraklı, açı fikirli, kuşkucu, alçak gönüllü ve sorgulayıcı özelliklerinin yetersizliğinden dolayı onların bilimsel tutum düzeylerinin belirlenmesi gerektiğini ortaya koymaktadır (MEB, 2016; OECD, 2016; Roy, 1996). Ayrica, Moore ve Foy (1997) bilimsel tutumların geliştirilmesinde öğretmenlerin sınıf içi ve dışındaki davranışlarının çok önemli olduğunu belirtmişlerdir. Buradan hareketle, bu çalışma lisede görev yapan fen disiplinlerinin öğretmenlerine de bir farkındalık kazandıracaktır. Dolayısıyla, lise öğrencilerine yönelik gerekçelerden hareketle, lise düzeyine uygun geçerli ve güvenilir bir ölçeğe ihtiyaç söz konusudur (Chuang ve Cheng, 2002).

Yapılan alan yazın taramasında, farklı öğrenim düzeylerindeki öğrencilerin (Afacan, 2008; Carin ve Bass, 2001; Chuang ve Cheng, 2002; Durmaz ve Mutlu, 2015; Pearson, 1993; Yenice ve Saydam, 2010) ve öğretmenlerin (Aslan ve Uluçınar, 2008; Gözüm, 2015; Polat, 2014) bilimsel tutum düzeylerini belirlemek amaciyla birçok çalışmanın yapıldığı görülmektedir. Öğrencilerin bilimsel tutumlarının belirlenmesine yönelik yapılan pek çok araştırmada, Demirbaş ve Yağbasan'ın (2006) Türkçeye uyarladığı ve ortaokul öğrencileri üzerinde geçerlik-güvenirlik çalışması yapılan bilimsel tutum ölçeği kullanılmıştır (Çelik ve Onay, 2014; Daşdemir, Cengiz ve Uzoğlu, 2015; Demirbaş ve Yağbasan, 2008; Emren, İrez ve Doğan, 2019; Erdoğan, 2013; Kanl1, 2017; Onay, Çelik ve Çağlayan, 2015; Öztürk ve Başbay, 2017; Önen Öztürk, 2016; Türkmen, 2002). Türkçeye uyarlanarak ortaokul düzeyinde analizleri yapılan bu ölçeğin, Türkiye'de daha üst öğretim basamaklarında öğrenim gören öğrencilerin bilimsel tutumlarını ölçmede eksik kalabileceği düşünülmektedir. Ayrıca alan yazında Duran (2008) tarafından geliştirilen bilimsel tutum ölçeği kullanılarak gerçekleştirilen çalışmalar yer almaktadır (örneğin, Mıhladız ve Duran, 2010). Bu ölçek toplam 19 maddeden oluşmaktadır. Ölçek geliştirilirken altı ve yedinci sınıf öğrencileri olmak üzere toplam 108 katılımcı ile çalışılmıştır. Ölçekteki madde sayısının en az 10 katı örneklem ile çalışılması gerektiği açısından değerlendirildiğinde (Nunnally, 1978), bu ölçeğin örneklem sayısı açısından sınırlı olduğu söylenebilir. Ayrıca bu ölçekte de ortaokul düzeyindeki öğrenciler dikkate alınarak değerlendirme yapilmıştır.

Alan yazında fen bilimleri dersine veya fen bilimlerinde bir alt alana yönelik tutumu inceleyen çalışmalar da yer almaktadır (Çelik ve Görgülü Arı, 2019; Hırça, 2012; Konu ve Gül, 2017; Şahin 2012; Yıldırım ve Kansız, 2017). Oysa ilköğretim ve lise düzeyinde fen bilimleri için olası tutumların içeriğine bakıldığında fen bilimlerinin 
sosyal içeriğinin yanı sıra bilim insanlarının yaşantısı ile ilgili durumlar, bilimsel tutumları kabullenme, bilimsel araştırmaya yönelik tutumlar gibi kavramları da kapsamakta olduğu dikkat çekmektedir (Osborne, Simon, ve Collins, 2003). Dolayısıyla, bilimsel tutumların, bir alt alana yönelik olarak değil, Moore ve Foy'un (1997) önerdiği gibi bilimsel özellikler ve davranışlar, bilim insanının ve bilimsel bilginin özellikleri ve bilim ve toplum arasındaki ilişki açlarından değerlendirilmesinin alan yazına farklı bir bakış açısı kazandıracağı öngörülmüştür.

Alan yazına bakıldığında, bilimsel tutum düzeyini belirlemeye yönelik çeşitli çalışmalar bulunmaktadır (Demirbaş ve Yağbasan, 2006; Duran, 2008; Lichtenstein, vd., 2008; Moore ve Foy, 1997; Yaşar ve Anagün, 2009). Buna rağmen, bu ölçeklerin güncel olmayışı, bireylerin davranışlarını ve karar verme sürecini ölçmeye yönelik yeterli maddeye sahip olmamaları, lise düzeyinde geçerlik ve güvenirlik çalışmalarının azlığı, örneklem sayısının sınırlılığı gibi unsurlar yeni bir ölçeğe ihtiyaç duyulduğunu göstermektedir. Bu kapsamda ortaöğretim düzeyindeki öğrencilerin bilimsel tutumlarının belirlenmesine yönelik geliştirilecek ölçeklerin kullanımı, öğretmenlere ve araştırmacılara yol gösterici olacaktır. Bu noktadan hareketle bu çalışmada, bilimsel bilginin özellikleri, bilim ve toplum ilişkisi, bilim insanı özellikleri ve bilimsel davranış sergileme gibi alt boyutlar dikkate alınarak bilimsel tutum ölçeğinin geliştirilmesi hedeflenmiştir. Bu anlayış doğrultusunda araştırmanın amacı; lise düzeyindeki öğrencilerin bilimsel tutumlarının tespit edilebilmesi için kullanılabilecek geçerli ve güvenilir bir ölçme aracının geliştirilmesidir.

\section{Yöntem}

\section{Araştırma Deseni}

Araştırmada nicel araştırma yönteminin desenlerinden birisi olan tarama (survey) deseni kullanılmıştır. Nicel araştırma yönteminin temel amacı; nesnel, nedensonuç ilişkisini sayısal verilere dayandırarak açıklayan ve örneklemden evrene genellenebilen bilgiye ulaşmaktır (Fraenkel ve Wallen, 2006). Tarama deseni, diğer desenlere göre büyük örneklemler kapsamında yürütülür ve bir konu ya da olay hakkında katılımcıların ilgi, beceri, görüş, tutum gibi niteliklerinin ortaya çıkarıldığı bir desendir (Fraenkel ve Wallen, 2006). Bu bağlamda, güncel araştırmada lise öğrencilerinin bilimsel tutum düzeylerinden faydalanılarak ölçek geliştirilmesi amaçlandığı için tarama deseni kullanılmıştır.

\section{Evren ve Örneklem}

Bu çalışmanın hedef evrenini 2019-2020 eğitim-öğretim yılında Kayseri ve Sivas illerinde öğrenim gören lise öğrencileri oluşturmaktadır. Hedef evren, ulaşılmak istenen fakat ulaşılması güç olan evrendir (Büyüköztürk, 2002). Bu çalışmanın ulaşılabilir evrenini ise 2019-2020 yılında Kayseri ili Talas ilçesi ve Sivas ili Altınyayla ilçesinde iki okulda öğrenim gören 9., 10., 11., ve 12. sınıf öğrencileri oluşturmaktadır. Ulaşılabilir evren, araştırmacının ulaşabileceği somut evrendir (Büyüköztürk, 2002). 
Bu çalışmada rastgele örneklemden faydalanılmıştır. Genelleme kaygısından dolayı rasgele örneklemin bir türü olan küme örnekleme tercih edilmiştir (Büyüköztürk vd., 2014). Çalışmanın örneklemini Kayseri ve Sivas iline bağlı iki lisede öğrenim gören 602 öğrenci oluşturmaktadır. Katılımcı sayısı kullanılan ölçekteki madde sayısının en az on katı olarak belirlenmiştir (Kline, 2005).

Tablo 1. Örneklemin demografik bilgileri

\begin{tabular}{llll}
\hline Değişken & Kategori & Sayı & Yüzde (\%) \\
\hline \multirow{2}{*}{ Cinsiyet } & Kadın & 320 & 53,20 \\
& Erkek & 282 & 46,80 \\
\hline \multirow{3}{*}{ Okul Türü } & Meslek Lisesi & 249 & 41,40 \\
& Anadolu Lisesi & 183 & 30,40 \\
& İmam Hatip Lisesi & 170 & 28,20 \\
\hline \multirow{3}{*}{ Sinıf } & 9 & 166 & 27,60 \\
& 10 & 152 & 25,20 \\
& 11 & 142 & 23,60 \\
& 12 & 142 & 23,60 \\
\hline
\end{tabular}

Bu bireylere ait demografik bilgilerin dağılımı Tablo 1'de verilmiştir. Doğrulayıcı faktör analizi çalışması dışında tüm analizler 602 katılımcının verilerine göre yürütülmüştür. Uygun örneklem yoluyla belirlenen 141 lise öğrencisine (82 kadın ve 59 erkek) ise ölçek doğrulayıcı faktör analizi çalışmasını yürütmek amacıyla uygulanmiştır.

\section{Veri Toplama Aracı}

Bu çalışmada "bilimsel tutumlar" konusunda 56 sorudan oluşan bir ölçeğin veri toplama aracı olarak geliştirilmesi amaçlanmıştır. Ölçekte 39 olumlu, 17 olumsuz madde bulunmaktadır. Ölçekte bulunan maddeler, Moore ve Foy (1997), Demirbaş ve Yağbasan (2006), Korkmaz, Şahin ve Yeşil (2011) ve Duran (2008) tarafından geliştirilen ölçeklerden alınarak, maddelerin bazıları aynen, bazı maddeler ise yeniden düzenlenerek ölçekte kullanılmıştır. Ayrıca, ölçekte yer alan bazı maddeler iki fen eğitimi uzmanının dönütleri doğrultusunda araştırmacılar tarafından yeniden düzenlenmiştir. Demirbaş ve Yağbasan tarafından geliştirilmiş olan 40 maddelik bilimsel tutum ölçeğinin Cronbach's Alpha güvenirlik katsayısı 0,76 olarak bulunmuştur. Korkmaz, Şahin ve Yeşil (2011) tarafından geliştirilen bilimsel araştırmaya yönelik tutum ölçeğinin Cronbach's Alpha güvenirlik katsayısı 0,77 ile 0,85 arasında olduğu tespit edilmiştir. Duran (2008) tarafında geliştirilen bilime karşı tutum ölçeğinin Cronbach's Alpha güvenirlik katsayısı 0,79 olarak hesaplanmıştır. Hazırlanan bu ölçek beşli likert tipinde düzenlenmiştir. Ölçekte puanlama yapılırken olumlu ifadeler için 1= Kesinlikle Katılıyorum, 2=Katılıyorum, 3=Kararsızım, 4=Katılmıyorum, 5=Kesinlikle Katılmıyorum şeklinde puanlanmıştır. Olumsuz ifadeler için ters puanlama yapılmıştır.

\section{Verilerin Analizi}


Ölçeğin geliştirilmesi aşamasında gerekli olan geçerlik ve güvenirlik analizleri için SPSS 22.0 ve LISREL 8.7 programları kullanılmıştır. Ölçekte yer alacağı düşünülen maddelerin normal dağılıp dağılmadığını belirlemek için çarpıklık ve basıklık katsayıları incelenmiştir. Ölçeğin kapsam geçerliğini sağlamak için 56 maddelik bir madde havuzu oluşturulmuştur. Bu havuzda yer alan maddeler, bilimsel tutum kavramının yapısal uygunluğuna dikkat edilerek seçilmiştir. Ölçek iki fen eğitimi uzmanı tarafından incelenerek verilen dönütler doğrultusunda düzenlenmiştir. Ölçeğin ölçüt geçerliğini belirlemek için paralel formlar yöntemi kullanılmış ve bu bağlamda Demirbaş ve Yağbasan (2006) tarafından geliştirilmiş olan ve bu araştırma kapsamında benzer tutumları ölçen bir ölçek kullanılmıştır. İki ölçek arasında Pearson korelasyon katsayılarına bakılmıştır. Ölçeğin yapı geçerliğini tespit etmek amacıyla KMO ve Bartlett testi analizleri yapılarak, bulunan değer kapsamında faktör analizi yapılıp yapılmayacağına karar verilmiştir. Elde edilen veriler ışığında açımlayıcı faktör analizi yapılmıştır. Ölçeğin kaç faktöre ayrıldığının belirlenmesi temel bileşenler analizi ile, ölçeğin alt boyutlarının arasındaki kuramsal ilişki Direct Oblimin eğik döndürme tekniği ile belirlenmiştir. Faktör yükü, $0,30^{\prime}$ dan düşük olan ve yükleri farklı faktörlerde birbirine yakın düzeyde olan maddeler çıkarılarak analizler tekrarlanmıştır (Tabachnick ve Fidell, 2013). Yapılan açımlayıcı faktör analiziyle dört faktörden oluştuğu belirlenen ölçeğin faktörlerinin doğrulanması için, doğrulayıcı faktör analizi yapılmıştır. Ölçeğin güvenirliğini belirlemek üzere iç tutarlılık katsayılarına bakılmıştır. İç tutarlılık düzeyinin belirlenmesinde Cronbach's Alpha güvenirlik katsayısı hesaplanmıştır. Ölçekten çıkarılan maddelerden sonra kalan 27 maddenin, madde ayırt edicilik indeksleri belirlenmiştir.

\section{Bulgular}

\section{Betimsel Analize İlişkin Bulgular}

$\mathrm{Bu}$ bölümde ölçekte yer alan maddelerin normal dağılım gösterip göstermediğine bakılmıştır. Bu kapsamda maddelerin çarpıklık ve basıklık katsayıları incelenmiştir.

Tablo 2. Maddelerin çarpıklık ve basıklık değerleri

\begin{tabular}{|c|c|c|c|c|c|c|c|c|}
\hline $\begin{array}{l}\text { Madde } \\
\text { No. }\end{array}$ & Çarpıklık & Basıklık & $\begin{array}{l}\text { Madde } \\
\text { No. }\end{array}$ & Çarpıklık & Basıklık & $\begin{array}{l}\text { Madde } \\
\text { No. }\end{array}$ & Çarpıklık & Basıklık \\
\hline M1 & 0,45 & $-0,28$ & M21 & 1,64 & $-0,49$ & M41 & 0,85 & $-0,52$ \\
\hline M2 & 1,113 & 0,56 & M22 & 1,51 & $-0,15$ & M42 & 1,08 & $-0,57$ \\
\hline M3 & 0,75 & $-0,54$ & M23 & 1,38 & 0,29 & M43 & 0,57 & $-0,24$ \\
\hline M4 & 1,00 & 0,52 & M24 & 1,25 & $-0,16$ & M44 & 0,17 & $-0,84$ \\
\hline M5 & 1,13 & 0,83 & M25 & 1,24 & 0,26 & M45 & 0,80 & 0,28 \\
\hline M6 & 0,81 & 0,20 & M26 & 1,39 & 1,98 & M46 & 0,75 & 0,66 \\
\hline M7 & 1,17 & $-0,08$ & M27 & 0,83 & 0,35 & M47 & 0,31 & $-0,77$ \\
\hline M8 & 0,97 & $-0,22$ & M28 & 1,12 & 0,78 & M48 & 0,60 & $-0,16$ \\
\hline M9 & 1,15 & $-0,22$ & M29 & 1,27 & 0,58 & M49 & 0,78 & $-1,14$ \\
\hline M10 & 0,88 & 0,35 & M30 & 0,81 & $-0,26$ & M50 & 0,92 & 1,64 \\
\hline
\end{tabular}




\begin{tabular}{lllllllll} 
M11 & 0,99 & 0,30 & M31 & 0,45 & $-0,80$ & M51 & $-0,18$ & 0,55 \\
M12 & 1,19 & $-0,66$ & M32 & 1,24 & $-0,74$ & M52 & 0,56 & $-0,10$ \\
M13 & 1,44 & $-0,74$ & M33 & 0,87 & 0,29 & M53 & 0,34 & 0,58 \\
M14 & 1,32 & $-0,77$ & M34 & 0,14 & 1,16 & M54 & $-0,74$ & $-0,48$ \\
M15 & 0,22 & $-0,99$ & M35 & 1,00 & $-0,66$ & M55 & 0,20 & $-0,95$ \\
\hline
\end{tabular}

Tablo 2 devami.

\begin{tabular}{lllllllll}
\hline $\begin{array}{l}\text { Madde } \\
\text { No. }\end{array}$ & Çarpıklık & Basıklı & $\begin{array}{l}\text { Madde } \\
\text { No. }\end{array}$ & Çarpıklık & Basıklık & $\begin{array}{l}\text { Madde } \\
\text { No. }\end{array}$ & Çarpıklık & Basıklık \\
\hline M16 & 1,47 & $-0,74$ & M36 & 1,14 & $-0,94$ & M56 & 0,83 & 0,29 \\
M17 & 1,30 & 0,83 & M37 & 0,90 & $-0,28$ & & & \\
M18 & 0,16 & $-0,94$ & M38 & 0,96 & 0,29 & & & \\
M19 & 0,57 & $-0,87$ & M39 & 0,16 & $-0,95$ & & & \\
M20 & 0,33 & 0,52 & M40 & 0,39 & $-1,11$ & & & \\
\hline
\end{tabular}

Tablo 2 incelendiğinde maddelerin çarpıklık ve basıklık değerlerinin (-2) ile (+2) arasında değiştiği görülmektedir. Çarpıklık ve basıklık değerlerinin (-2) ile (+2) arasında olması öğrencilerin maddelerden aldıkları puanların normal dağıldığını gösterir (George ve Marley, 2016, s.11). Dolayısıyla, ölçekte yer alan maddelerden öğrencilerin aldığı puanların normal dağılım gösterdiği söylenebilir.

\section{Ölçeğe Yönelik Geçerlik Çalışması}

Geçerlik, bir amaç doğrultusunda hazırlanan testin amaca hizmet etme derecesi olarak ifade edilebilir (Fraenkel ve Wallen, 1996). Bu kısımda ölçeğin geçerlik çalışması çerçevesinde; kapsam, ölçüt ve yapı geçerliğine ilişkin bulgular verilmiştir.

\section{Kapsam Geçerliğine İlişkin Bulgular}

Ölçeğin oluşturulması noktasında alan yazında yer alan bilimsel tutum ölçekleri incelenmiş, iki fen eğitimi alan uzmanından görüş alınmış ve bilimsel tutum kavramının yapısı ve özellikleri dikkate alınarak 39 olumlu ve 17 olumsuz, toplamda 56 maddelik bir madde havuzu oluşturulmuştur. Taslak ölçek iki fen eğitimi alan uzmanı tarafından incelenmiş, uzman görüşleri doğrultusunda gerekli düzenlemeler yapılmıştır. Ölçek uzmanlar tarafından kapsam geçerliliği, dil bilgisi, anlam ve biçim özellikleri açısından değerlendirilmiştir. Ölçekte bulunan birçok maddenin orijinali Moore ve Foy (1997) ölçeğinde yer almaktadır. Bu ölçekte bulunan maddelerin boyutları da, mevcut çalışmanın ölçeğinin faktörleri oluşturulurken dikkate alınmıştır. Mevcut ölçekte yer alan maddeler Türk araştırmacıların çalışmalarında da yer almıştır. Dolayısıyla, mevcut ölçekte bulunan 20 madde Demirbaş ve Yağbasan (2006) tarafından geliştirilen ölçekten, altı madde Korkmaz, Şahin ve Yeşil (2011) tarafından geliştirilen ölçekten, altı madde Duran (2008) tarafından geliştirilen ölçekten alınıp yeniden düzenlenmiştir. Örneğin "Bilimsel kanunlar tüm muhtemel şüphelere rağmen kanıtlanmışlardır" maddesi "Bilimsel bilgilerin kanıtlanmış bilgiler olduğunu düşünüyorum" şeklinde düzenlenmiştir. Ayrıca, "Bilimsel araştırmalar fen bilimlerine özgüdür, sosyal bilimlerde olamaz" maddesi "Bilimsel araştırmaların fen bilimlerine özgü olup, sosyal bilimleri kapsamadığı düşünüyorum” şeklinde, “Geçmişteki önemli 
bilim insanlarının hayat öykülerini ve buluşlarını merak ederim" maddesi "Bilim insanlarının hayat hikâyelerini ve buluşlarını merak ederim" şeklinde ifade edilmiştir. Tablo 3'te, yapılan tüm analizler sonucunda kalan 27 madde, yanına parantez açılarak çarpı işareti $(X)$ koyularak gösterilmiştir. Çarpı koyulmayan maddeler ise ölçekten çıkarılan maddelerdir.

Tablo 3. Ölçekte bulunan maddeler ve alıntılandığı kaynaklar

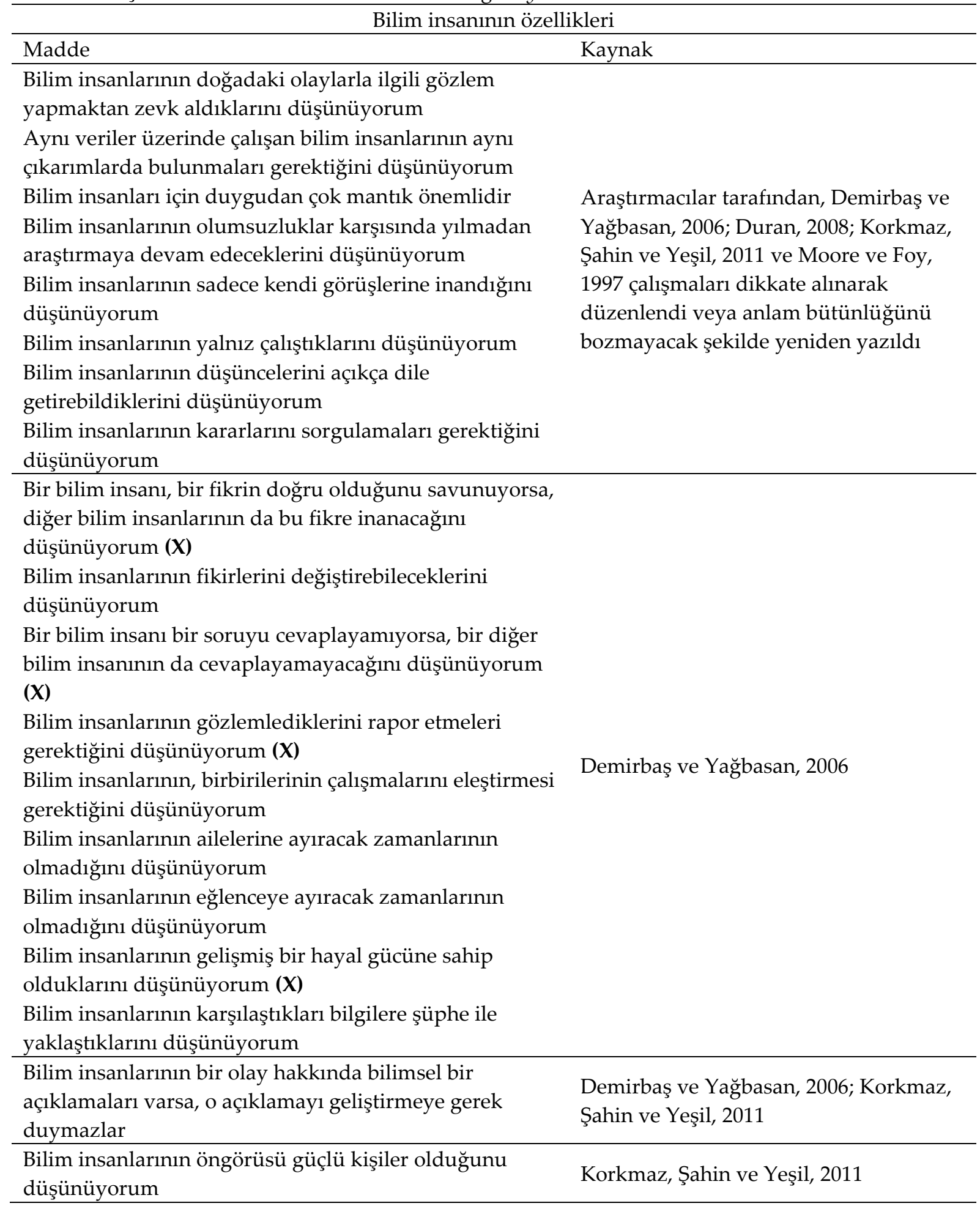




\begin{tabular}{ll}
\hline \multicolumn{2}{c}{ Bilim ve toplum } \\
\hline Bilimin toplumu olumlu yönde etkilediğini & Araştırmacılar tarafından, Demirbaş ve \\
düşünüyorum (X) & Yağbasan, 2006; Duran, 2008; Korkmaz, \\
& Şahin ve Yeşil, 2011 ve Moore ve Foy, \\
Bilimsel araştırmaların yeni sorunlar ortaya çıkardığını & 1997 çalışmaları dikkate alınarak \\
düşünüyorum (X) & düzenlendi veya anlam bütünlüğünü \\
& bozmayacak şekilde yeniden yazıl \\
\hline
\end{tabular}

Tablo 3 devamı.

\begin{tabular}{|c|c|}
\hline \multicolumn{2}{|c|}{ Bilim ve toplum } \\
\hline Madde & Kaynak \\
\hline $\begin{array}{l}\text { Bilimsel araştırma sonuçlarının yaşamı kolaylaştırdığını } \\
\text { düşünüyorum }(\mathbf{X}) \\
\text { Bilimsel araştırmaların sadece bilim insanları için faydalı } \\
\text { olduğunu düşünüyorum }(\mathbf{X )}\end{array}$ & \\
\hline $\begin{array}{l}\text { Bilimsel araştırma sonuçlarını sadece eğitim seviyesi } \\
\text { yüksek bilim insanlarının anlayacağını düşünüyorum } \\
\text { İnsanların bilimi anlama yeteneğinden yoksun } \\
\text { olduğunu düşünüyorum } \\
\text { Bilimsel gelişmeleri takip ederim }(\mathbf{X})\end{array}$ & Demirbaş ve Yağbasan, 2006 \\
\hline $\begin{array}{l}\text { Bilimsel araştırma sonuçlarının insanları } \\
\text { kaygılandırdığını düşünüyorum }\end{array}$ & Korkmaz, Şahin ve Yeşil, 2011 \\
\hline \multicolumn{2}{|c|}{ Bilimsel Bilginin Özellikleri } \\
\hline $\begin{array}{l}\text { Bilimsel araştırmaların çevremizdeki sorunlara çözüm } \\
\text { yolu bulmamızı sağladığını düşünüyorum }(X) \\
\text { Bilimsel araştırma sonuçlarının eleştirilmesi gerektiğini } \\
\text { düşünüyorum } \\
\text { Bilimsel araştırmalarda mantık ve hayal gücünün } \\
\text { birlikte kullanıldığını düşünüyorum }(X)\end{array}$ & $\begin{array}{l}\text { Araştırmacılar tarafından, Demirbaş ve } \\
\text { Yağbasan, 2006; Duran, 2008; Korkmaz, } \\
\text { Şahin ve Yeşil, } 2011 \text { ve Moore ve Foy, } \\
1997 \text { çalışmaları dikkate alınarak } \\
\text { düzenlendi veya anlam bütünlüğ̈ünü } \\
\text { bozmayacak şekilde yeniden yazıldı }\end{array}$ \\
\hline $\begin{array}{l}\text { Bilimsel araştırmaların her soruyu cevaplayacağını } \\
\text { düşünüyorum }(\mathbf{X )} \\
\text { Bilimsel fikirlerin değişeceğini düşünüyorum }(\mathbf{X})\end{array}$ & \\
\hline $\begin{array}{l}\text { Bilimsel bilgilerin kanitlanmış bilgiler olduğunu } \\
\text { düşünüyorum }(\mathbf{X})\end{array}$ & Demirbaş ve Yağbasan, 2006 \\
\hline $\begin{array}{l}\text { Bilimsel soruların gözlem yapılarak cevaplanacağını } \\
\text { düşünüyorum }\end{array}$ & \\
\hline $\begin{array}{l}\text { Bilimsel araştırmaların fen bilimlerine özgü olduğunu } \\
\text { düşünüyorum }\end{array}$ & Korkmaz, Şahin ve Yeşil, 2011 \\
\hline $\begin{array}{l}\text { Bilimin doğa olaylarını anlamamızı sağladığını } \\
\text { düşünüyorum }(\mathbf{X})\end{array}$ & Duran, 2008 \\
\hline
\end{tabular}

\begin{tabular}{|c|c|}
\hline \\
\hline \multicolumn{2}{|l|}{ Kararlarımı sorgularım } \\
\hline Bilimsel araştırmaların nasıl yapıldığını merak ederim & Araştırmacılar tarafından, Demirbaş ve \\
\hline$(\mathrm{X})$ & Yağbasan, 2006; Duran, 2008; Korkmaz, \\
\hline Boş zamanlarımda bilimsel içerikli dergiler okumaktan & Şahin ve Yeşil, 2011 ve Moore ve Foy, \\
\hline hoşlanırım & 1997 çalışmaları dikkate alınarak \\
\hline Bir bilginin doğruluğunu kanıtlamak isterim & düzenlendi veya anlam bütünlüğünü \\
\hline Çevremdeki sorunları çözmeye istekliyimdir (X) & bozmayacak şekilde yeniden yazıldı \\
\hline Doğanın işleyişini anlamak isterim & \\
\hline Üzerinde uzlaşılmayan fikirleri dinlemek istemem & Demirbaş ve Yağbasan, 2006 \\
\hline
\end{tabular}


Bilimsel araştırmalar yaparken eğlenirim (X)

Bilimsel araştırma yapmak benim için zordur (X)

\begin{tabular}{ll}
\hline $\begin{array}{l}\text { Bilimsel araştırma yapanlara yardım etmek hoşuma } \\
\text { gider }(\mathbf{X})\end{array}$ & $\begin{array}{l}\text { Demirbaş ve Yağbasan, 2006; Korkmaz, } \\
\text { Şahin ve Yeşil, 2011 }\end{array}$ \\
\hline Gelecekte bilim insanı olmak istemem & $\begin{array}{l}\text { Demirbaş ve Yağbasan, 2006; Duran, } \\
2008\end{array}$ \\
Bilimsel bilgiyi araştırırken sıkılırım & \\
\hline
\end{tabular}

Tablo 3 devamı

\begin{tabular}{|c|c|}
\hline \multicolumn{2}{|c|}{ Bilimsel Davranış Sergileme } \\
\hline Madde & Kaynak \\
\hline $\begin{array}{l}\text { Sorunlarımı bilimsel araştırma yöntemlerini kullanarak } \\
\text { çözmeye çalışırım } \\
\text { Bilimsel araştırmaları önemserim }(\mathbf{X}) \\
\text { Bilimsel araştırmalara katkı sağlamak isterim }(\mathbf{X})\end{array}$ & Korkmaz, Şahin ve Yeşil, 2011 \\
\hline $\begin{array}{l}\text { Bilim insanlarının hayat hikâyelerini ve buluşlarını } \\
\text { merak ederim (X) } \\
\text { Bilimsel gelişmeler ilgimi çeker }(\mathbf{X}) \\
\text { Bilimsel içerikli belgeseller izlemekten hoşlanırım (X) } \\
\text { Bilimsel konularla ilgili tartışmaya katılmaktan zevk } \\
\text { alırım (X) } \\
\text { Doğadaki olaylarla ilgili gözlem yapmaktan zevk alırım } \\
(\mathbf{X )}\end{array}$ & Duran, 2008 \\
\hline
\end{tabular}

Bazı maddeler (20 adet) önceki anlamları bozulmayacak şekilde araştırmacılar tarafından yeniden düzenlenmiştir. Alan yazın taraması yapılarak oluşturulan madde havuzu ve maddelerin kapsadığı alt boyutlar Tablo 3 'te sunulmuştur. Tablo 3 incelendiğinde, her bir maddenin hangi kaynaktan alındığı görülmektedir. Ayrıca maddelerin bilimin, "Bilim İnsanlarının Özellikleri", "Bilim ve Toplum", "Bilimsel Bilginin Özellikleri" ve "Bilimsel Davranış Sergileme" gibi alt boyutları göz önüne alınarak seçildiği görülmektedir.

\section{Ölçüt Geçerliğine İlişkin Bulgular}

Bu çalışmada, ölçüt geçerliliğini sağlamak için benzer tutumları ölçen Demirbaş ve Yağbasan'ın (2006) ölçeği ölçüt ölçek olarak belirlenmiştir. Demirbaş ve Yağbasan'ın (2006) ölçeğinde bulunan 10 madde farklı kazanımlar ölçtüğü için çıkarılmış ve sonuç olarak 30 maddelik bir ölçüt ölçek elde edilmiştir. Her iki ölçeğinde örneklemdeki 110 kişiye rastgele uygulanmasından sonra SPSS 22.0 paket programında ölçüt ölçekten ve çalışmanın durumuna uygun hale getirilerek düzenlenen mevcut ölçeğin son halinden elde edilen puanlar arasındaki korelasyon katsayıları incelenmiştir. Korelasyon katsayılarına bakılmasında değişkenler arasındaki ilişkiyi keşfetmek amaçlanmıştır (Pallant, 2017).

Tablo 4.Ölçekler arasındaki korelasyon katsayı sonuçları

\begin{tabular}{clcr}
\hline Ölçek & Korelasyon & Bilimsel tutum & \multicolumn{2}{c}{ Ölçüt } \\
\hline Bilimsel Tutum & Pearson Korelasyon & 1 & $0,79^{* *}$
\end{tabular}




\begin{tabular}{llll}
\hline & Anlamlılık Değeri & & 0,00 \\
& Kişi Sayısı & 110 & 110 \\
\hline \multirow{3}{*}{ Ölçüt } & Pearson Korelasyon & $0,79^{* *}$ & 1 \\
& Anlamlılık Değeri & 0,00 & 110 \\
\hline & Kişi Sayısı & 110 & \\
\hline
\end{tabular}

Ölçüt geçerliğini sağlamak için Pearson korelasyon katsayısı 0,70 ve üzerinde bir değere sahip olması beklenir (Pallant, 2017). Tablo 4'e bakıldığında iki ölçek arasındaki korelasyon katsayısı değeri 0,79 bulunmuş ve ölçüt geçerliği sağlanmıştır. Dolayısıyla, ölçüt ölçek ile bu araştırma için kullanılan ölçeğin bilimsel tutumlar açısından benzer kazanımları ölçtügü belirlenmiştir.

\section{Yapı Geçerliğine İlişkin Bulgular}

Bu çalışmada ölçeğin yapı geçerliğini sağlamak için ilk olarak açımlayıcı (AFA) faktör analizi sonrasında ise doğrulayıcı (DFA) faktör analizi yapılmıştır. AFA, SPSS 22.0 programı ile DFA ise LISREL 8.7 programı ile yapılmıştır.

\section{Açımlayıcı Faktör Analizi (AFA)}

Ölçeğe faktör analizi yapılıp yapılamayacağını belirlemek için KMO ve Barlett testi sonuçları incelenmiştir. Verilere açımlayıcı faktör analizi yapabilmek için KaiserMeyer-Olkin (KMO) değerinin anlamlı olması gerekmektedir. KMO değerinin 0,60'dan yüksek olması verilerin normal dağıldığını göstermektedir (Seçer, 2017).

Tablo 5. KMO ve Bartlett's testi sonuçları

\begin{tabular}{lll}
\hline Kaiser-Meyer-Olkin Örneklem Yeterliliği. & & 0,80 \\
\hline Bartlett Küresellik Testi & Yaklaşık Ki-Kare & 7662,33 \\
& Df & 683 \\
& Anlamlılık Değeri & 0,00 \\
\hline
\end{tabular}

Tablo 5 'te de görüldüğü gibi, KMO değeri 0,80 bulunmuştur. Dolayısıyla, bulunan değer faktör analizinin yürütülebileceğini ve örneklemin yeterli olduğunu ifade etmektedir (Pallant, 2017). Tablo 5'te verilen Barlett's testi sonuçları da istatistiksel olarak anlamlı olduğundan bu durumu doğrulamaktadır.

Faktör analizi sonuçlarının değerlendirilmesinde faktör yükleri, maddeler ve değişkenlerle faktörler arasındaki ilişkiyi anlamlandıran temel ölçütlerdir (Balcı, 2009). Faktör yüklerinin fazla olması, gözlenen değişkenin belirtilen faktör altında bulunabileceğinin bir göstergesi olarak düşünülmektedir (Büyüköztürk, 2002). Faktör analizi yapılırken, bir ölçekteki maddelerin kaç faktöre ayrılacağını ortaya çıkarmak amacıyla "Temel Bileşenler Analizi" tekniği sıklıkla kullanılmaktadır (Büyüköztürk, 2002; Pallant, 2017). Öte yandan Direct Oblimin eğik döndürme tekniği de ölçeğin alt boyutları arasında ilişki olduğu varsayıldığında kullanılabilmektedir (Seçer, 2017). 
Tablo 6. Maddelerin çıkarım değerleri

\begin{tabular}{llllll}
\hline Madde No. & Çıkarım Değeri & Madde No. & Çıkarım Değeri & Madde No. & Çıarım Değeri \\
\hline M1 & 0,50 & M21 & 0,56 & M41 & 0,36 \\
M2 & 0,52 & M22 & 0,49 & $\mathbf{M 4 2}$ & 0,46 \\
M3 & 0,40 & M23 & 0,42 & M43 & 0,54 \\
M4 & 0,47 & M24 & 0,54 & $\mathbf{M} 4$ & 0,46 \\
M5 & 0,52 & M25 & 0,40 & M45 & 0,34 \\
M6 & 0,55 & M26 & 0,39 & M46 & 0,46 \\
\hline
\end{tabular}

Tablo 6 devamı.

\begin{tabular}{llllll}
\hline Madde No. & Çıkarım Değeri & Madde No. & Çıkarım Değeri & Madde No. & Çıkarım Değeri \\
\hline M7 & 0,44 & M27 & 0,41 & M47 & 0,52 \\
M8 & 0,35 & M28 & 0,41 & M48 & 0,42 \\
M9 & 0,36 & M29 & 0,51 & M49 & 0,32 \\
M10 & 0,54 & M30 & 0,55 & M50 & 0,37 \\
M11 & 0,38 & M31 & 0,41 & M51 & 0,42 \\
M12 & 0,39 & M32 & 0,35 & M52 & 0,36 \\
M13 & 0,55 & M33 & 0,42 & M53 & 0,35 \\
M14 & 0,54 & M34 & 0,51 & M54 & 0,46 \\
M15 & 0,46 & M35 & 0,44 & M55 & 0,49 \\
M16 & 0,47 & M36 & 0,42 & M56 & 0,36 \\
M17 & 0,39 & M37 & 0,38 & & \\
M18 & 0,40 & M38 & 0,34 & & \\
M19 & 0,55 & M39 & 0,46 & & \\
M20 & 0,36 & M40 & 0,45 & & \\
\hline
\end{tabular}

Bu kapsamda, öncelikle ölçeğin boyutların belirlemek amacıyla temel bileşenler analizi yapılmıştır. Ölçeğin alt boyutlarının arasındaki kuramsal ilişkiyi görmek için ise Direct Oblimin eğik döndürme tekniği kullanılmıştır. Yapılan analiz sonucunda ölçekte bulunan maddelerin çıkarım (extraction) değerlerine bakılmıştır. Tablo 6'da maddelerin çıkarım değerleri gösterilmiştir.

Çıkarım değeri, her bir maddenin açıkladığı madde varyansını belirtir. Her bir maddenin açıkladığı ortak varyans değerinin en az 0,10 olması istenir (Seçer, 2017). Tablo 6'ya bakıldığında her bir maddenin "çıkarım" değerinin 0,10 değerinin üzerinde olduğu görülmektedir. Dolayısıyla, ölçekten bu nedenle hiçbir maddenin çıkarılmayacağı söylenebilir. Yapılan analiz sonucunda beş faktörlü bir yapıya ulaşılmıştır. Bir maddenin birden fazla madde altına girmesi ve bu iki maddenin yük sayıları arasındaki farkın 0,10' dan az olması o maddenin binişik olduğu anlamına gelmektedir (Pallant, 2017). Bu nedenle 18 madde binişik çıktığından dolayı ikinci bir analiz yapılarak yapı dört faktöre sınırlandırılmıştır. Bu işlem sonrasında 11 maddenin daha binişik olduğu görülmüştür. Bu maddeler çlkarılarak yapılan üçüncü faktör analizi sonucunda birinci faktör on iki maddeden, ikinci faktör dört maddeden, üçüncü faktör beş maddeden, dördüncü faktör ise altı maddeden oluşmuştur. 
Faktörlerin isimlendirilmesi yapılırken, maddelerin altında toplandıkları faktörler dikkate alınarak maddelerin içeriklerinin anlamsal uygunluğuna bakılır (Çakır, 2014). Birinci faktör altında toplanan maddeler incelendiğinde, bilimsel davranış sergileme hakkındaki ifadeler bulunmaktadır. Bu sebeple birinci faktöre "Bilimsel Davranış Sergileme" ismi verilmiştir. İkinci faktör altında toplanan maddelere bakıldığında, bilim insanın özellikleri hakkında ifadeler bulunmaktadır. $\mathrm{Bu}$ sebeple ikinci faktöre "Bilim İnsanı Özellikleri" ismi verilmiştir. Üçüncü faktör altında toplanan maddeler incelendiğinde, bilim ve tolum hakkındaki ifadeler yer almaktadır. Bu noktadan hareketle üçüncü faktöre "Bilim ve Toplum" ismi verilmiştir. Dördüncü faktör altında toplanan maddeler incelendiğinde ise bilimsel bilginin özellikleri hakkında ifadeler içermektedir. Dolayısıyla dördüncü faktöre "Bilimsel Bilginin Özellikleri" ismi verilmiştir.

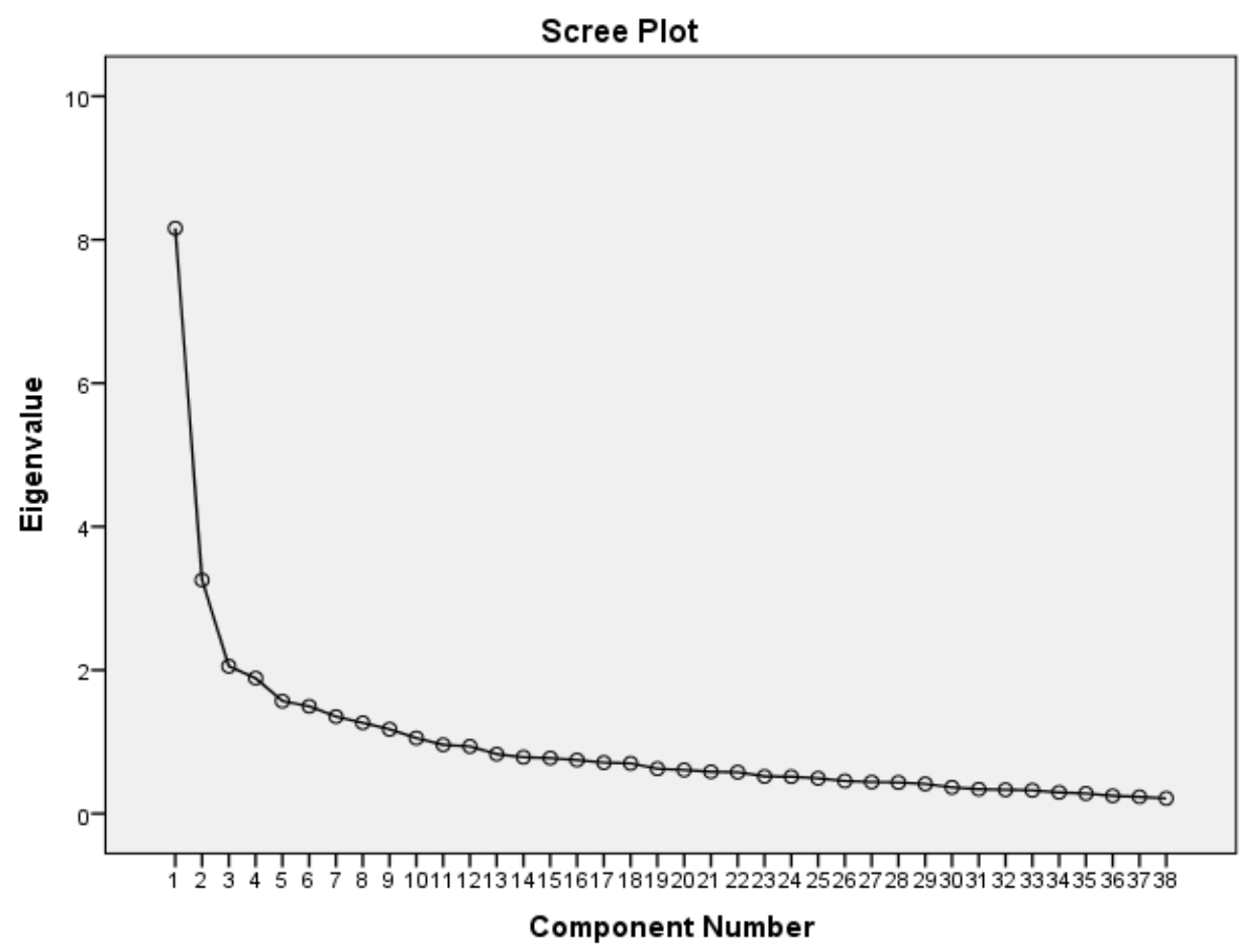

Şekil 1. Yamaç birikinti ĕgrisi

Şekil 1'de maddelerin yamaç birikinti eğrisi verilmiştir. İniş eğilimi görülen noktadan itibaren iki nokta arasındaki her aralık bir faktör anlamına gelmektedir (Çokluk, Şekercioğlu ve Büyüköztürk, 2010). Faktörlerin yamaç birikinti eğrisine bakıldığında da dört faktörlü yapının doğru olduğu görülmüştür.

Tablo 7. Faktör yük değerleri

\begin{tabular}{|c|c|c|c|c|}
\hline \multirow[b]{2}{*}{ Madde } & \multicolumn{4}{|c|}{ Faktörler } \\
\hline & $\begin{array}{l}\text { Bilimsel davranış } \\
\text { sergileme }\end{array}$ & $\begin{array}{l}\text { Bilim insanlarının } \\
\text { özellikleri }\end{array}$ & Bilim ve toplum & Bilimsel bilginin özellikleri \\
\hline
\end{tabular}




\begin{tabular}{ll} 
M15 & 0,75 \\
M41 & 0,74 \\
M13 & 0,66 \\
M10 & 0,61 \\
M39 & 0,58 \\
M33 & 0,57 \\
M43 & 0,57 \\
M7 & 0,56 \\
M21 & 0,56 \\
M37 & 0,54 \\
M26 & 0,53 \\
\hline
\end{tabular}

Tablo 7 devam1.

\begin{tabular}{|c|c|c|c|c|}
\hline \multirow[b]{2}{*}{ Madde } & \multicolumn{4}{|c|}{ Faktörler } \\
\hline & $\begin{array}{l}\text { Bilimsel davranış } \\
\text { sergileme }\end{array}$ & $\begin{array}{l}\text { Bilim insanlarının } \\
\text { özellikleri }\end{array}$ & Bilim ve toplum & Bilimsel bilginin özellikleri \\
\hline M9 & & 0,74 & & \\
\hline M36 & & 0,68 & & \\
\hline M16 & & 0,66 & & \\
\hline M30 & & 0,61 & & \\
\hline M51 & & & 0,58 & \\
\hline M40 & & & 0,57 & \\
\hline M1 & & & 0,49 & \\
\hline M53 & & & 0,49 & \\
\hline M14 & & & 0,36 & \\
\hline M56 & & & & 0,68 \\
\hline M6 & & & & 0,60 \\
\hline M20 & & & & 0,56 \\
\hline M5 & & & & 0,53 \\
\hline M25 & & & & 0,50 \\
\hline M47 & & & & 0,41 \\
\hline
\end{tabular}

Ölçekte yer alan faktörlerin altında toplanan maddelerin faktör yükleri incelenmiş ve bulgular Tablo 7'de verilmiştir. Bir faktörün altına giren maddenin faktör yükünün en az 0,30 olması gerekmektedir (Tabachnick ve Fidell, 2013). Bu noktadan hareketle Tablo 7 incelendiğinde bütün faktör yüklerinin $0,30^{\prime}$ dan büyük olduğu görülmektedir.

Tablo 8. Maddeler için açıklanan toplam varyans değgerleri

\begin{tabular}{llllllll}
\hline \multicolumn{2}{l}{ Başlangıç öz değerleri } & \multicolumn{5}{c}{ Toplam faktör yükleri } \\
\hline & Toplam & Varyans \% & Kümülatif \% & Toplam & Varyans \% & Kümülatif \% & Toplam \\
\hline $\mathbf{1}$ & 8,16 & 21,47 & 21,47 & 8,16 & 21,47 & 21,47 & 6,11 \\
$\mathbf{2}$ & 3,26 & 8,57 & 30,04 & 3,26 & 8,57 & 30,04 & 4,24 \\
$\mathbf{3}$ & 2,05 & 5,41 & 35,45 & 2,05 & 5,41 & 35,45 & 4,30 \\
$\mathbf{4}$ & 1,89 & 4,97 & 40,41 & 1,89 & 4,97 & 40,41 & 4,06
\end{tabular}




\begin{tabular}{llll}
\hline $\mathbf{5}$ & 1,57 & 4,13 & 44,54 \\
$\mathbf{6}$ & 1,50 & 3,94 & 48,48 \\
$\mathbf{7}$ & 1,35 & 3,56 & 52,04 \\
$\mathbf{8}$ & 1,27 & 3,33 & 55,37 \\
$\mathbf{9}$ & 1,18 & 3,09 & 58,46 \\
$\mathbf{1 0}$ & 1,05 & 2,77 & 61,23 \\
$\mathbf{1 1}$ & 0,96 & 2,52 & 63,75 \\
$\mathbf{1 2}$ & 0,94 & 2,47 & 66,22 \\
$\mathbf{1 3}$ & 0,83 & 2,18 & 68,40 \\
$\mathbf{1 4}$ & 0,79 & 2,07 & 70,47 \\
$\mathbf{1 5}$ & 0,77 & 2,04 & 72,50 \\
$\mathbf{1 6}$ & 0,75 & 1,96 & 74,47 \\
$\mathbf{1 7}$ & 0,71 & 1,87 & 76,34 \\
$\mathbf{1 8}$ & 0,70 & 1,85 & 78,18 \\
$\mathbf{1 9}$ & 0,63 & 1,65 & 79,83 \\
\hline
\end{tabular}

\section{Tablo 8 devam1.}

\begin{tabular}{llllllll}
\hline \multicolumn{3}{l}{ Başlangıç öz değerleri } & \multicolumn{5}{c}{ Toplam faktör yükleri } \\
\hline & Toplam & Varyans \% & Kümülatif \% & Toplam & Varyans \% & Kümülatif \% & Toplam \\
\hline $\mathbf{2 0}$ & 0,61 & 1,60 & 81,43 & & & & \\
$\mathbf{2 1}$ & 0,58 & 1,53 & 82,96 & & & \\
$\mathbf{2 2}$ & 0,58 & 1,52 & 84,48 & & & \\
$\mathbf{2 3}$ & 0,52 & 1,36 & 85,85 & & & \\
$\mathbf{2 4}$ & 0,51 & 1,35 & 87,20 & & & \\
$\mathbf{2 5}$ & 0,49 & 1,29 & 88,49 & & & \\
$\mathbf{2 6}$ & 0,45 & 1,20 & 89,69 & & & \\
$\mathbf{2 7}$ & 0,44 & 1,16 & 90,85 & & & \\
\hline
\end{tabular}

Tablo 8'de maddeler için açıklanan toplam varyans değerleri görülmektedir. Tablo 8 incelendiğinde, ölçek çerçevesinde bulunan maddelerin ve faktörlerin toplam varyansın \%40,41'ni açıkladığı görülmüştür. Bu kapsamda varyans miktarının \%40 olması yeterli olduğu belirtilmektedir (Büyüköztürk, 2002). Ayrıca, ölçeğin sahip olduğu toplam varyans oranının $\% 40$ ile $\% 60$ değerleri arasında olması faktör yapısının güçlü olduğunu göstermektedir (Scherer, Wiebe, Luther ve Adams, 1988; akt. Bakaç, 2013).

\section{Doğrulayıcı Faktör Analizi (DFA)}

Açımlayıcı faktör analizinin sonucunda dört faktörden oluştuğu belirlenen ölçeğin faktörlerinin doğrulanması amacıyla, doğrulayıcı faktör analizi yapılmıştır. DFA araştırmacının elinde bulunan orijinal verilerin, yapısal uygunluğunu belirlemek amacıyla kullanılmaktadır (Seçer, 2017). Bu faktörlerin doğruluğunu kanıtlamak için LISREL 8.7 programı kullanılarak doğrulayıcı faktör analizi yapılmıştır. Bu yapılan analizle birlikte doğrulanan maddelerin sonuçları Şekil 2' de verilmiştir. Doğrulayıcı faktör analizinde, ki-kare testi (chi-square) sonuçlarına bakılmıştır. Bulunan ki kare değerinin df değerine bölünmesi sonucunda elde edilen değer beş (5) veya altında ise yapı kabul edilebilir bir değerdir (Hooper ve Mullen, 2008; Munro, 2005; Şimşek, 2007). Ki kare $(1556,35)$ serbestlik derecesine (318) bölündüğünde, 4,89 değeri elde edilmiştir. 
Dolayısıyla bu değerin analiz için kabul edilebilir olduğu söylenebilir. Ayrıca RMSEA $(0,080)$ değeri 0,050 ve 0,080 arası olmasından dolayı kabul edilebilir sınır içinde olduğu belirlenmiştir (Seçer, 2017). Faktörlerin doğrulandığını tam olarak söyleyebilmek için uyum indekslerine de bakılmalıdır.

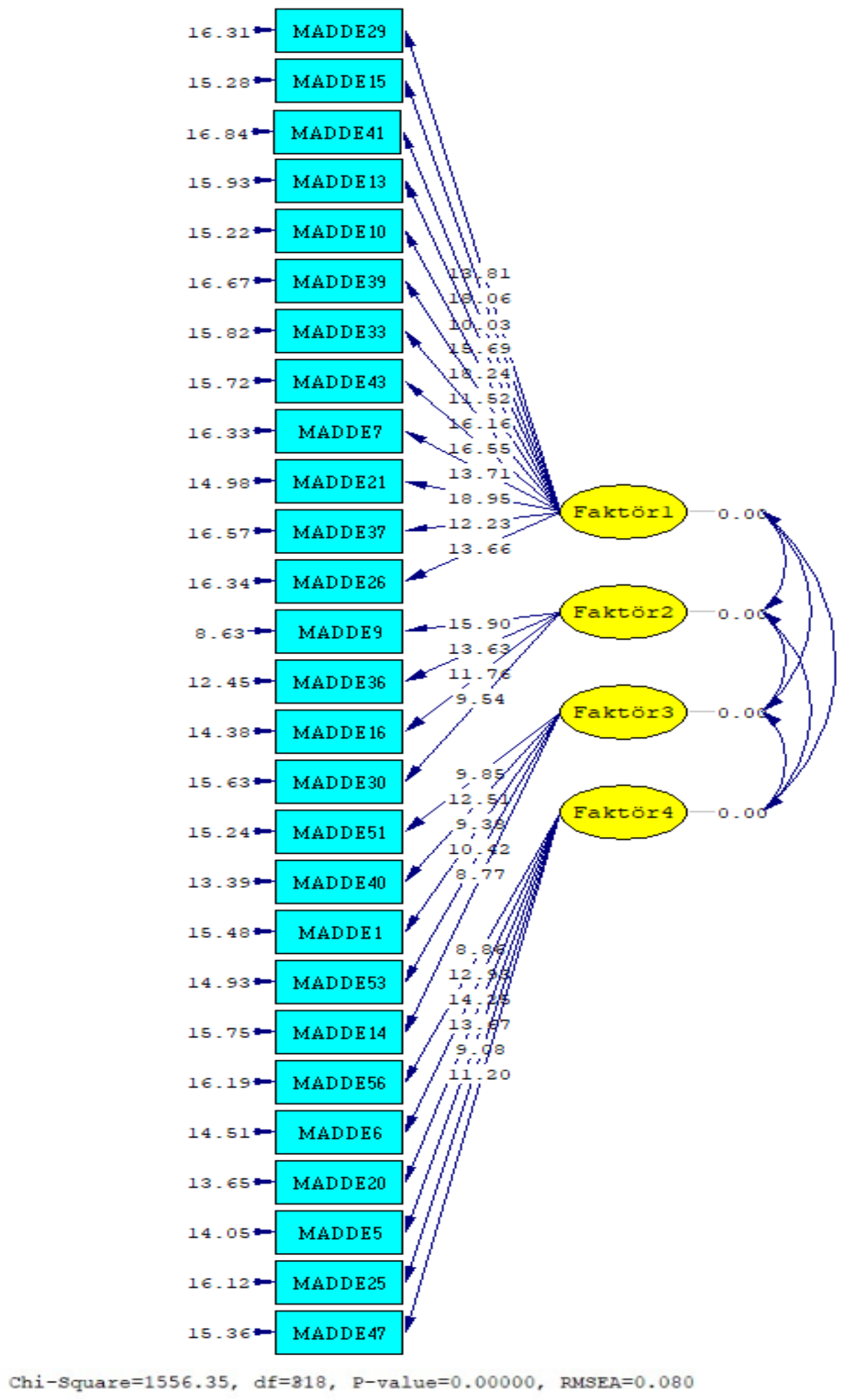

Şekil 2. DFA sonuçları PATH diyagramı 
Dört faktörlü yapıyı doğrulayabilmek için analiz sonucu elde edilen model uyum indeksleri ile alan yazında verilen model uyum indekslerinin karşılaştırılması gerekir (Schumacher ve Lomax, 2004). Bu çalışmada elde edilen model uyum indekslerinin istenilen aralıkta veya değerde olduğu belirlenirse dört faktörlü yapı doğrulanmış olur.

Tablo 9. Kabul edilebilir değer, mükemmel uyum ve bilimsel tutum ölçeğinin uygun değerleri

\begin{tabular}{lllc}
\hline Uyum kriteri & Kabul edilebilir sınır & Mükemmel uyum sınırı & Bilimsel tutum ölçeği sinırı \\
\hline NFI & $=0,90$ ve üzeri & $=0,95$ ve üzeri & 0,91 \\
NNFI & $=0,90$ ve üzeri & $=0,95$ ve üzeri & 0,90 \\
IFI & $=0,90$ ve üzeri & $=0,95$ ve üzeri & 0,90 \\
RFI & $=0,90$ ve üzeri & $=0,95$ ve üzeri & 0,91 \\
CFI & $=0,95$ ve üzeri & $=0,97$ ve üzeri & 0,90 \\
GFI & $=0,85$ ve üzeri & $=0,90$ ve üzeri & 0,85 \\
AGFI & $=0,85$ ve üzeri & $=0,90$ ve üzeri & 0,87 \\
RMR & $=0,050$ ve $=0,080$ arası & $=0,000$ ve $<0,050$ arası & 0,069 \\
RMSEA & $=0,050$ ve $=0,080$ arası & $=0,000$ ve $<0,050$ arası & 0,080 \\
\hline
\end{tabular}

Tablo 9'da verilen, verilerden yola çıkarak DFA ile ölçekte bulunan faktörlerin doğrulandığı ve uyum indekslerinde kabul edilebilir sonuçlara sahip olduğu belirlenmiştir. Dolayısıyla, açımlayıcı faktör analizi doğrulanmıştır ve ölçeğin son hali dört faktörlü yapıya sahip, 27 maddeden oluşturulmuştur.

\section{Ölçeğin Güvenirliğine İlişkin Bulgular}

Güvenirlik en temel anlamıyla ölçme sonuçlarının kararlılık derecesidir (Seçer, 2017). Ölçeğin iç tutarlığının tespitinde sıklıkla “Cronbach's Alpha" güvenirlik katsayısı kullanılır (Pallant, 2017).

Tablo 10. Güvenirlik istatistiği

\begin{tabular}{lll}
\hline Ölçek & Cronbach's Alfa güvenirlik katsayısı & Madde Sayısı \\
\hline İlk Hali & 0,86 & 56 \\
Son Hali & 0,87 & 27 \\
\hline
\end{tabular}

Tablo 10'da güvenirlik istatistiğine ilişkin sonuçlar verilmiştir. Bu çalışmada geliştirilen ölçekten örneklemdeki kişilerin aldığı puanların güvenirlik katsayısı 0,87 olarak bulunmuştur. İdeal bir ölçeğin Cronbach's Alpha güvenirlik katsayısının 0,70 ve üzerinde bir değerde olması istenir (Pallant, 2017).

Tablo 11. Faktörlerin "Cronbach's Alpha" güvenirlik değerleri

\begin{tabular}{lll}
\hline Faktörler & Maddeler & Katsayı \\
\hline Bilimsel Davranış Sergileme & $7,10,13,15,21,26,29,33,37,39,41,43$ & 0,86 \\
Bilim İnsanlarını Özellikleri & $9,16,30,36$ & 0,70 \\
Bilim ve Toplum & $1,14,40,51,53$ & 0,75 \\
Bilimsel Bilginin Özellikleri & $5,6,20,25,47,56$ & 0,78 \\
\hline
\end{tabular}


Tablo 11'de elde edilen dört faktör için de güvenirlik katsayıları görülmektedir. $\mathrm{Bu}$ değerler incelendiğinde, faktörlerin altında toplanan maddelerin güvenirlik değerlerinin 0,70 değerinin üzerinde olduğu görülmektedir. Dolayısıyla, katılımcıların her faktörden aldığı puanlar güvenilirdir.

\section{Sonuç, Tartışma ve Öneriler}

Bu çalışmada, lise öğrencilerinin bilimsel tutumlarını tespit etmek amacıyla bir ölçek geliştirilmiştir. Ölçeğin geliştirilmesinde, ölçeğin hedefleri, bilimsel tutum kavramı ve özellikleri incelenmiştir. Bu kapsamda hazırlanan ölçek beşli Likert tipinde olup dört faktör altında toplanan 27 maddeden oluşmuştur. Bu çalışmaya benzer şekilde yapılmış olan bilimsel araştırmaya yönelik tutum ölçeği geliştirme çalışmasında da dört faktörlü yapıya ulaşılmıştır (Korkmaz, Şahin ve Yeşil, 2011). Ölçeğin, "Bilimsel Davranış Sergileme", "Bilim İnsanlarının Özellikleri", "Bilim ve Toplum" ve "Bilimsel Bilginin Özellikleri" isimleriyle dört faktörlü bir yapıya sahip olduğu sonucuna ulaşılmıştır. Çalışmanın başlangıcında 56 maddesi bulunan ölçeğin bazı maddeleri analiz sonucunda çalışmadığı için çıkarılmıştır. Bu durum, ilgili maddelerin katılımcıların bu dört faktör altındaki özelliklerini ölçmede yetersiz kaldığ 1 şeklinde yorumlanabilir. Ayrıca maddeler kültürden kültüre, bölgeden bölgeye değişik anlamlar taşıyabilir. Geçerlik güvenirlik çalışması için belirlenen maddeler hem Moore ve Foy (1997) gibi yabancı bir kültürden, hem de Demirbaş ve Yağbasan (2006), Korkmaz, Şahin ve Yeşil (2011) Duran (2008) gibi ulusal bir çalışmadan elde edilmiştir. Dolayısıyla Kayseri örneklemindeki lise öğrencilerinin maddelere yüklediği anlam belirtilen dört çalışma ile de farklılıklar göstermektedir. Bu çalışmanın örneklemindeki katılımcılar "Bilimsel davranış sergileme" maddelerine daha fazla anlam yüklemiş ve ölçekte bu faktör altında 12 maddenin olmasını sağlamışlardır.

Ölçek iki fen eğitimi uzmanı tarafından kapsam geçerliliği, dil bilgisi, anlam ve biçim özellikleri açısından değerlendirilmiştir. $\mathrm{Bu}$ değerlendirme sonucu bazı maddeler anlamını bozmayacak şekilde tamamen değişikliğe uğramışlardır. Araştırmacıların düzenlediği maddelerden altı tanesi ölçekte kalmıştır. Özellikle "Bilim insanının özellikleri" faktörünün altında araştırmacıların düzenlediği hiçbir maddenin yer almaması dikkat çekicidir. Bu maddeler Roy'un da (1996) belirttiği gibi lise öğrencilerinin meraklı, açık fikirli, kuşkucu, alçak gönüllü ve sorgulayıcı özelliklerini ölçen maddelerdir ve bu maddelerin bu ölçekte yer alamaması ölçeğin bir eksikliği olarak değerlendirilebilir.

Ölçeğin ölçüt geçerliğini belirlemek için Demirbaş ve Yağbasan (2006) tarafından geliştirilmiş olan ve bu araştırma kapsamında benzer tutumları ölçen bir ölçek kullanılmıştır. İki ölçeğin puanları arasındaki Pearson korelasyon katsayı değerinin 0,79 olarak bulunması ile mevcut ölçeğin ölçüt geçerliğini sağladığı sonucuna ulaşılmıştır. Bu sonucu doğrulayan durum ise mevcut ölçekte Demirbaş ve 
Yağbasan'ın (2006) çalışmasında kullandığı 21 maddenin kullanılmasıdır. Bu maddelerden bazıları her ne kadar düzeltilerek kullanılsa da ölçüt ölçekteki maddeler ile aynı kazanımları ölçmesi bahsedilen korelasyon değerinin yüksek çıkmasının kanitı olabilir.

Çalışmada KMO değeri 0,80 olarak bulunmuştur. KMO testi örneklem yeterliğinin bir göstergesi olarak görülebilir (Er ve Ünal, 2016). Yüksek KMO değeri, ölçekteki her bir değişkenin, diğer değişkenler tarafından yordanabilirliğinin çok iyi olduğunu ve faktör analizi yapılabileceğini gösterir. KMO değerinin 0,80 üzerinde olması faktör analizinin yapılabileceğinin göstergesidir (Çokluk, Şekercioğlu ve Büyüköztürk, 2010). Faktörleri belirlemek için hem açımlayıcı hem de doğrulayıcı faktör analizi yapılmıştır. Faktörlerdeki maddelerin açıklanan varyans oranları, faktörlerin öz değerleri ve yükleri incelendiğinde, ölçeğin yapı kapsamında geçerli olduğu söylenebilir. Bu kapsamda ölçekteki maddelerin toplam varyansın en az $\% 40^{\prime} ı$ ıı açıklaması ve faktör yüklerinin $0,30^{\prime}$ dan yüksek olmasının yeterli olduğu belirtilmektedir (Pallant, 2017). Yapılan açımlayıcı faktör analiziyle dört faktörden oluştuğu belirlenen ölçeğin faktörlerinin doğrulanması için doğrulayıcı faktör analizi yapılmıştır. Yapılan analiz sonucunda, açımlayıcı faktör analizinde elde edilen verilerin doğrulandığı görülmüştür. Dolayısıyla, ölçekteki her maddenin ve faktörün ölçeğin kapsamında ölçülmek istenen özelliği ölçebilme amacına sahip olduğu söylenebilir.

Ölçeğin iç tutarlığı için Cronbach's Alpha güvenirlik katsayıları incelenmiştir. Cronbach's Alpha iç tutarlık katsayısı mevcut ölçek için 0,87 olarak bulunmuştur. Alan yazında bu çalışmaya benzer şekilde yapılmış ve bazı maddeleri bu ölçekte kullanılan bilimsel tutum ölçeğinin Cronbach's Alpha iç tutarlık katsayısı ise 0,76 olarak bulunmuştur (Demirbaş ve Yağbasan, 2006). Dolayısıyla, geliştirilmiş olan bu ölçeğin iç tutarlık katsayısının iyi olduğu söylenebilir. Güvenirlik katsayıları incelenirken her bir maddenin yer aldığ ${ }_{1}$ faktörlerinde güvenirlikleri analiz edilmiştir. Elde edilen sonuçlar kapsamında ölçeğin güvenilir ölçümler yapabildiği söylenebilir. Nitekim güvenirlik katsayının 0,70 ve üzerinde olması, ölçekten elde edilen puanların güvenilir olduğunu gösterir (Can, 2014).

Ölçekte her bir madde için ayrı veya toplam puan hesaplanabilmektedir. Ölçek ile alınabilecek minimum puan 28 , maksimum puan ise $108^{\prime}$ dir. Ölçekten yüksek puan alınması, bireylerin bilimsel tutum düzeylerinin yükseldiğini, düşük puan alınması bilimsel tutum düzeylerinin düştügüünü gösterir. Sonuç olarak geliştirilen bilimsel tutum ölçeğinin, lise düzeyinde eğitim gören öğrencilerin bilimsel tutumlarının belirlenmesine yönelik kullanılabilir, geçerli ve aynı zamanda güvenilir bir araç olduğu söylenebilir. Konuyla ilgili araştırma yapmak isteyen araştırmacılar geliştirilen ölçeği kullanarak lise düzeyindeki öğrencilerin bilimsel tutum düzeylerini belirleyebilirler. Ölçekte bulunan maddeler belirlenirken uzman kişilerin görüşleri alınmıştır. Araştırmacıların belirlediği bazı maddelerin ölçekte yer alamamasından dolayı, maddeler belirlenirken ilave olarak öğrencilerle görüşmeler yapılabilir. Ayrıca 
araştırmacılar bilimsel tutumlar çerçevesinde daha kapsamlı bilgilere ulaşmak amacıyla farklı örneklem grupları ile çalışmalar yapabilir, nitel araştırma yöntemi kullanılarak çalışmalarını sürdürebilirler.

\section{Etik Beyan}

“Bilimsel Tutum Ölçeği Geliştirme: Geçerlik ve Güvenirlik Çalışması" başlıklı çalışmanın yazım sürecinde bilimsel, etik ve alıntı kurallarına uyulmuş; toplanan veriler üzerinde herhangi bir tahrifat yapılmamış ve bu çalışma herhangi başka bir akademik yayın ortamına değerlendirme için gönderilmemiştir.

\section{Kaynaklar}

Afacan, Ö. (2008). İlköğretim öğrencilerinin fen-teknoloji-toplum-çevre (FTTÇ) ilişkisini algılama düzeyleri ve bilimsel tutumlarmın tespiti: Kırşehir ili örneği. Yayımlanmamış Doktora Tezi, Gazi Üniversitesi, Eğitim Bilimleri Enstitüsü.

Aslan, O., \& Uluçınar Sağır, Ş. (2008). Fen ve teknoloji öğretmen adaylarının bilimsel tutumlarının, öz yeterlik inanç düzeylerinin ve etki eden faktörlerin belirlenmesi. Proceedings of the 8th International Education Technology Conference, 868- 873.

Bacanlı, H. (2005). Duygusal davranış eğitimi. Nobel Yayınclık.

Bakaç, E. (2013). Toplumsal değerlere yönelik algı ölçeği: geçerlik ve güvenirlik çalışması. Eğitim ve Öğretim Araştırmaları Dergisi, 2(4), 303-309.

Balcı, A. (2009). Sosyal Bilimlerde Araştırma: Yöntem, Teknik ve Illkeler. PegemA Yayıncılık.

Baykul, Y. (1990). Ilkokul beşinci sinfftan lise ve dengi okulların son sinfflarma kadar matematik ve fen derslerine karşı tutumda görülen değişmeler. Ankara: ÖSYM Yayınları.

Brown, S. J., Sharma, B. N., Wakeling, L., Naiker, M., Chandra, S., Gopalan, R. D., \& Bilimoria, V. B. (2014). Quantifying attitude to chemistry in students at the University of the South Pacific. Chemistry Education Research and Practice, 15(2), 184-191.

Büyüköztürk, D. (1999). İlköğretim okulu öğretmenlerinin araştırma yeterlikleri. Kuram ve Uygulamada Eğitim Yönetimi, 18(18), 257-269.

Büyüköztürk, Ş. (2002). Sosyal bilimler için veri analizi el kitabı. PegemA Yayınclık.

Büyüköztürk, S., Kılıç Çakmak, E., Akgün, O. E., Karadeniz, S., \& Demirel, F. (2014). Bilimsel araştırma yöntemleri (16. Baskı). PegemA Yayıncllı.

Can, A. (2014). SPSS ile bilimsel araştırma sürecinde nicel veri analizi (2. Baskı). Pegem A Yayıncilik.

Carin, A. A., \& Bass, J. E. (2001). Methods for Teaching Science as Inquiry. Prentice Hall Inc. Eighty Edition.

Chan, J. Y. K., \& Bauer, C. F. (2015). Effect of peer-led team learning (PLTL) on student achievement, attitude, and self-concept in college general chemistry in 
randomized and quasi experimental designs. Journal of Research in Science Teaching, 52(3), 319-346. https://doi.org/10.1002/tea.21197

Cheung, D. (2009). Students' attitudes toward chemistry lessons: The interaction effect between grade level and gender. Research in Science Education, 39(1), 75-91. https://doi.org/10.1007/s11165- 007-9075-4

Chuang, H. F., \& Cheng, Y. J. (2002). The relationships between attitudes toward science and related variables of junior high school students (Article Written in Chinese), Chinese Journal of Science Education 10 (1), 1-20.

Çakır, A. (2014). Faktör Analizi, Doktora Tezi, İstanbul Ticaret Üniversitesi, İstanbul.

Çelik, Y., \& Onay, I. (2014). Altıncı sınıf öğrencilerinin bilimsel tutumları ve özgüvenleri arasındaki ilişkinin çeşitli değişkenlere göre incelenmesi. Asian Journal of Instruction, 2(2), 38-51.

Çelik, B., \& Görgülü Arı, G. (2019). Ortaokul öğrencilerinin bilim ve fen bilimleri dersine yönelik tutumları. Academic Perspective Procedia, 2(1), 76-82.

Çokluk, Ö., Şekercioğlu, G., \& Büyüköztürk, Ş. (2010). Sosyal bilimler için çok değişkenli istatistik SPSS ve LISREL uygulamaları. Pegem Akademi.

Daşdemir, İ., Cengiz, E., \& Uzoğlu, M. (2015). Öğrenme amaçlı yazma aktivitelerinden mektup yazmanın yedinci sınıf ışık ünitesinde öğrencilerin akademik başarılarına ve bilimsel tutumlarına etkisi. Ordu Üniversitesi Sosyal Bilimler Araştırmaları Dergisi, 5 (11), 89-103.

Demirbaş M., \& Yağbasan, R. (2005). Sosyal öğrenme teorisine dayalı öğretim etkinliklerinin, öğrencilerin bilimsel tutumlarının kalıcılığına olan etkisinin incelenmesi. Uludağ Üniversitesi Eğitim Fakültesi Dergisi, 18 (2), 363-382.

Demirbaş, M., \& Yağbasan, R, (2006). Fen bilgisi öğretiminde bilimsel tutumların işlevsel önemi ve bilimsel tutum ölçeğinin Türkçeye uyarlanma çalışması. Uludă̆ Üniversitesi Ĕ̆itim Fakültesi Dergisi, 19(2), 271-299.

Demirbaş, M., \& Yağbasan, R. (2008). İlköğretim altıncı sınıf öğrencilerinin bilimsel tutumlarının geliştirilmesinde sosyal öğrenme teorisi etkinliklerinin kullanılması. Fırat Üniversitesi Sosyal Bilimler Dergisi, 18(1), 105-120

Duran, M. (2008). Fen öğretiminde bilimsel süreç becerilerine dayalı öğrenme yaklaşımının öğrencilerin fene yönelik tutumlarına etkisi. Yüksek Lisans Tezi, Muğla Üniversitesi Fen Bilimleri Enstitüsü, Muğla.

Durmaz, H., \& Mutlu, S. (2015). Bilimsel süreç becerilerini vurgulayan öğretimsel uygulamaların yedinci sınıf öğrencilerinin bilimsel tutum ve fen öğrenmeye yönelik motivasyonları üzerine etkisi. Trakya Üniversitesi Sosyal Bilimler Dergisi, 17(1), 143-162.

Emren, M., İrez, S., \& Doğan, Ö. (2019). Bilim tarihi destekli işlenen "canlılarda enerji dönüşümleri" ünitesinin, öğrencilerin bilime ve biyoloji dersine olan tutumları ve bilimin doğası anlayışları üzerine etkisinin incelenmesi. Trakya Eğitim Dergisi, 9 (3), 527-548. 
Er, K., \& Ünal, T. (2016). Ortaokul öğrencilerine yönelik dil bilgisi tutum ölçeği geliştirilmesi: Geçerlilik ve güvenirlik çalışması. Mehmet Akif Ersoy Üniversitesi Eğitim Fakültesi Dergisi, 1(40), 343-356.

Erdem, A. R. (2012). Bilim insanı yetiştirmede etik eğitimi. Yükseköğretim ve Bilim Dergisi, 2(1), 25-32.

Erdoğan, S. (2013). Üstün zekâlı kızların bilime yönelik tutumları ve bilim insanı imajları. HAYEF Journal of Education, 10(1), 125-142.

Fraenkel, J. K., \& Wallen, N. E. (1996). How to design and evaluate research in education (3. edition). New York: McGraw-Hill, Inc.

Gömleksız, M., \& Kan, A. (2012). Eğitimde duyuşsal boyut ve duyuşsal öğrenme. Electronic Turkish Studies, 7(1), 1559-1177.

Gözüm, A. (2015). Okul öncesi, sinıf ve fen bilgisi öğretmenlerinin fen bilimleri öz yeterliklerine göre sosyo-bilimsel tutum ve bilişsel yapılarının belirlenmesi: Kars ili örneği. Doktora Tezi, Ondokuz Mayıs Üniversitesi Eğitim Bilimleri Enstitüsü, Samsun.

Hadden, R. A., \& Johnstone, A. H. (1983). Secondary school pupils' attitudes to science: the year of erosion. European Journal of Science Education, 5, 309-318.

Hırça, N. (2012). Bağlam temelli öğrenme yaklaşımına uygun etkinliklerin öğrencilerin fizik konularını anlamasına ve fizik dersine karşı tutumuna etkisi. Mustafa Kemal Üniversitesi Sosyal Bilimler Enstitüsü Dergisi, 9(17), 313-325.

Hooper, C. J., \& Mullen, MR (2008). Structural equation modeling: guidelines for determining model fit. The Electronic Journal of Business Research Methods, 6(1), 53-60.

Jewett, T. O. (1996). And They Is Us: Gender Issues in The Instruction of Science. Eric.

Kanlı, E. (2017). Üstün yetenekli öğrencilerin bilimsel yaratıcılık düzeyleri, cinsiyet ve bilimsel tutumları arasındaki ilişkilerin incelenmesi. Elementary Education Online, 16(4), 1792-1802.

Kline R. B. (2005). Principles and practice of structural equation modeling. Guilford Press; 154-186.

Korkmaz, Ö., Şahin, A., \& Yeşil, R. (2011). Bilimsel araştırmaya yönelik tutum ölçeği geçerlilik ve güvenirlik çalışması. Ilköğretim Online, 10(3), 961-973.

Lichtenstein, M. J., Owen, S. V., Blalock, C. L., Liu, Y., Ramirez, K. A., Pruski, L. A., \& Toepperwein, M. A. (2008). Psychometric reevaluation of the scientific attitude inventory-revised (SAI-II). Journal of Research in Science Teaching, 45(5), 600-616.

McCoach, D.B., Gable, R \& Madura, J. P. (2013). Instrument development in the affective domain. Springer.

Milli Eğitim Bakanlığı. (MEB). (2018). Ortä̈̆retim 9., 10., 11. ve 12. sinff fizik, kimya ve biyoloji dersi öğretim programı. Talim ve Terbiye Kurulu Başkanlığı. Ankara.

Mıhladız, G., \& Duran, M. (2010). İlköğretim öğrencilerinin bilime yönelik tutumlarının demografik değişkenler açısından incelenmesi. Mehmet Akif Ersoy Üniversitesi Ĕ̆itim Fakültesi Dergisi, 1 (20), 100-121. 
Moore, R. W. \& Foy, R. L. H. (1997). The scientific attitudes inventory: A revision (SAI II). Journal of Research in Science Teaching, 34, 327-341.

Munro, B. (2005). Statistical methods for health care research (Vol. 1) p.351-76.

Nieswandt, M. (2007). Student affect and conceptual understanding in learning chemistry. Journal of Research in Science Teaching, 44(7), 908-937. doi: 10.1002/tea.20169

Nunnally, J. C. (1978). Psychometric theory. McGraw Hill.

OECD. Publishing. (2016). Society at a glance 2016: OECD social indicators. OECD publishing.

Olasehinde, K. J., \& Olatoye, R. A. (2014). Scientific attitude, attitude to science and science achievement of senior secondary school students in Katsina State, Nigeria. Journal of Educational and Social Research, 4(1), 445-452.

Onay, İ., Çelik, Y., \& Çağlayan, K. (2015). Altıncı sınıf öğrencilerinin bilimsel tutumlarının bazı değişkenlere göre incelenmesi. Asya Öğretim Dergisi, 3(2), 44.

Osborne, J., Simon, S., \& Collins, S. (2003). Attitudes towards science: A review of the literature and its implications. International journal of science education, 25(9), 1049-1079. DOI: https://doi.org/10.1080/0950069032000032199

Önen Öztürk, F. (2016). Bilimsel epistemolojik inançlar, bilimsel bilginin doğası hakkındaki görüşler ve bilimsel tutumlar üzerine bir çalışma: Abu Dhabi Örneği. Muğla Sıtkı Koçman Üniversitesi Ĕ̆itim Fakültesi Dergisi, 3 (2), 16-29.

Öztürk, A., \& Başbay, A. (2017). Mevlana toplum ve bilim merkezi öğretim programlarının öğrencilerin bilimsel süreç becerilerine ve bilime yönelik tutumlarına etkisi. Kastamonu Ĕ̆itim Dergisi, 25(1), 283-298.

Pallant, J. (2017). SPSS kullanma kılavuzu. Anı yayıncılık.

Pearson, E. M. (1993). Effects of teachers' instructional method of the nature of scientific knowledge and scientific attitudes on students' understanding of the nature of scientific knowledge and scientific attitude. Doctorate thesis, University of Massachusetts Lowell, Massachusetts.

Polat, M. (2014). Eğitim fakültesi öğrencilerinin bilimsel araştırmaya yönelik tutumları. Pamukkale Üniversitesi Sosyal Bilimler Enstitüsü Dergisi, (18), 77- 90.

Rao, D. B. (1996). Scientific attitude vis-à-vis scientific aptitude. Discovery Publishing House.

Schumacher, R., \& Lomax, G. (2004). A Beginner's Guide to Structural Equation Modeling. Mahwah, New Jersey: Lawrence Erlbaum Associates.

Seçer, İ. (2017). SPSS ve LISREL ile pratik veri analizi. Anı yayıncılık.

Şimşek, Ö. (2007). Yapısal eşitlik modellemesine giriş:(Temel ilkeler ve LISREL uygulamalarl). Ekinoks.

Tabachnick, G., \& Fidell, S. (2013). Using multivariate statistics (Sixth edition). Pearson Prentice Hall.

TUIK Türkiye İstatistik Kurumu [Turkish Statistical Institute], (2018). Gençlik İstatistik Raporu. Retrieved from http://www.tuik.gov.tr. 
Türkmen, L. (2002). Sınıf öğretmenliği birinci sınıf öğrencilerinin fen bilimleri ve fen bilgisi öğretimine yönelik tutumları. Hacettepe Üniversitesi Eğitim Fakültesi Dergisi, 23(23), 218-228.

Yaşar, Ş., \& Anagün, Ş. S. (2009). Reliability and validity studies of the science and technology course scientific attitude scale. Journal of Turkish Science Education, 6(2), 43-54.

Yenice, N., \& Saydam, G. (2010). 8th grade students' science attitudes and views about nature of scientific knowledge. Journal of Qafqaz University, 29(1), 89- 97.

Yıldırım, H., \& Kansız, F. (2017). Ortaokul öğrencilerinin fen dersine yönelik tutum düzeylerinin bazı değişkenler açısından incelenmesi. 2. Electronic Turkish Studies, 12(25), 779-806. 